Gert, Heather J. "Rights and Rights Violators: A New Approach to the Nature of Rights," Journal of Philosophy, Dec. 1990, 688-694.

Made available courtesy of Journal of Philosophy: http://www.journalofphilosophy.org/

\title{
RIGHTS AND RIGHTS VIOLATORS: A NEW APPROACH TO THE NATURE OF RIGHTS*
}

I $\mathrm{n}$ today's world, there is much talk about rights: women's rights, minorities' rights, children's rights, animals' rights, etc. There are groups devoted to seeing to it that each possible right is recognized and respected. And some philosophers have taken it upon themselves to defend the very existence of rights. Why are rights seen to be so important?

Let me suggest that much of the importance we attach to rights derives from our desire to think of ourselves as qualitatively different from the "lower" animals. Part of what makes us different, so the story goes, is that we have more rights than they do, and that our rights are more significant than theirs (both in the sense that we have rights that are in themselves more significant than the rights had by other animals, such as our right to liberty; and in the sense that, in the event of there being a conflict between a person and another animal in respect to what seems to be the same right, say the "right to life," it is always the person's right that is supreme).

Perhaps it is this perceived link between the superiority of persons over animals and the superiority of the rights of persons over the rights of animals that has led so many philosophers to pursue the question 'what is a right?' by considering what it is about persons which differentiates them from "mere" animals. An extension of this line of reasoning has then led them to wonder precisely which beings have rights and in virtue of which of their properties is it that they have these rights.

In opposition to this approach, I would like to suggest that consideration of the properties of a particular being in isolation provides insufficient data to determine the rights of that being; and, furthermore, that the nature of rights in general cannot be determined solely by consideration of the characteristics of those who are said to have rights. (Most of the discussion in this paper will be in terms of human rights but, as I hope will be clear, I take it that what I have to say can easily be extended to talk of any kind of rights—natural rights, legal rights, etc.)

One who holds that a being's rights can be determined by consideration of that being alone might well begin by claiming, in somewhat

\footnotetext{
* I would like to thank Norman Care, Dan Brock, and Bernard Gert for their helpful comments and, even more, for the encouragement they gave me while working on this paper.
} 
more precise language, that sentient beings such as ourselves have the right not to be caused pain, and to add that such beings have this right in virtue of something having to do with their sentience. It is a commonplace, however, to note that broadly phrased rights claims such as this will not do. The dentist to whom I go to have a cavity filled does not violate a right of mine simply because her drilling causes me pain. Nor does the cavity, which caused the toothache, violate my right.

My proposal is that we consider a new question: In virtue of what do we say that a being is capable of violating (or respecting) a right? It may seem strange to consider what can violate, or "break," a right in order to discover something about rights. Certainly we do not discover much about china vases by considering small children and bulls. Nevertheless, I believe we will find that this question sheds as much light on the nature of rights as does the seemingly more appropriate question: In virtue of what does a being have a right?

To begin our discussion, let us imagine the following scenario: Allison, a fully competent adult person, is sitting at home, quietly reading in her favorite armchair. Suddenly, a crash breaks the stillness of the evening, and Bertha appears in front of her. Bertha leaps at Allison and violently attacks her. Just as suddenly, Bertha disappears, leaving Allison with a broken arm, and covered with scratches and bruises. Can we say of Allison that her rights have been violated?

No doubt it is tempting to say that the above paragraph clearly describes a situation in which a person's rights have been violated. It must be recognized, however, that this is tempting only because we have made certain assumptions about Bertha. But, in fact, we have been told nothing about her. She may be something more or less in keeping with our assumptions, say, a hostile youth who wantonly beats unsuspecting persons. But perhaps she is a tormented paranoid schizophrenic, mistakenly released from a mental institution, or a wild bear that has wandered into Allison's home from a nearby forest.

Most will agree that, if Bertha is a hostile youth, then Allison's rights have been violated, whereas if Bertha is a wild bear, they have not. There will be more disagreement, I believe, over the case in which Allison has been attacked by Bertha the schizophrenic. ${ }^{1}$

\footnotetext{
${ }^{1}$ There are at least two factors that complicate the case of Bertha the paranoid schizophrenic. First, we are not sure how to assess the rational capabilities of a paranoid schizophrenic: Are we to evaluate his actions on the basis of his beliefs, in which case actions such as those of Bertha may be justified? Or are we to evaluate his actions on the basis of the "real" situation, in which case such actions are often
} 
These various evaluations can only be correct if it is true that, in determining whether or not a certain act constitutes the violation of a right, we in fact do take into account not only the characteristics of that which is said to hold the right, but also the characteristics of that which performs the action said to violate the right.

Actions, the external appearances of which are identical, will or will not be said to violate a right depending on whether or not a person ${ }^{2}$ is performing the action. So, a human-looking robot that malfunctions and stabs a person would not be said to have violated a right, whereas a person going through precisely the same motions would be said to be violating a right. (A robot that is programmed to stab a person probably is a means toward violating that person's right; nevertheless, it is not the robot that violates the right.) Or, to make the same point from the opposite direction, the animals and objects of children's stories can violate rights precisely because they are to be considered as persons. A malicious tea kettle that manages to spill boiling water on someone will be said to have violated that person's right not to be hurt. A real tea kettle that does what appears to be exactly the same thing will not be said to have violated anyone's right.

I would now like to suggest that the criteria that an entity must meet in order to be said to violate another's rights are more stringent than the criteria that an entity must meet in order to be said to have rights. To see this, consider the scene between Allison and Bertha in reverse-in this case Allison unprovokedly attacks Bertha. Most would agree that under any of the three descriptions of Bertha it would be said that Allison has violated her rights; and there is no doubt that, under either of the first two descriptions of Bertha (as a hostile youth, or as a paranoid schizophrenic), her rights will be said to have been violated. To take another example: if a small child, in the throes of a temper tantrum, injures an adult, we will not say that the child has violated the adult's rights. If, however, an adult in the throes of a tantrum inflicts comparable injuries on a small child, most of us will say that the child's rights have been violated.

Let us stop to consider the case in which a child harms an adult.

unjustified. Is a paranoid schizophrenic unable to recognize and respect the rights of others? If he is unable to recognize and respect the rights of others he cannot have violated Allison's right.

The second factor to take into account is that others may have duties concerning Bertha the schizophrenic such that they will be said to have violated Allison's right by releasing Bertha.

2 Although I am not going to attempt to define 'person', it should be noted that I do not intend it to be understood as synonymous with 'human being'. 
Let us imagine that she bites him. If the child is a newborn, we would certainly not say that she has violated a right of the adult. Nor are we likely to say that the adult's right has been violated by a toddler in her testing stage. By the time the child is five, however, many will say that she violates the adult's right when she bites him. And by the age of eight or ten almost all would agree that the child does violate the adult's right.

Whether or not one contends that human beings grow into their rights, we will all agree that we grow into our ability to recognize and respect the rights of others (and therefore that we grow into the ability to violate them as well). The newborn is presumably unable to differentiate between her own actions and the actions of those around her, and so it would be inappropriate to hold her responsible for her actions (if she can even be properly said to act). It is probably also inappropriate to hold a toddler to be morally responsible for her actions, but at this age the child is aware of being the originator of her own actions, and so it is now appropriate to attempt to affect her behavior through some sort of discipline. By the age of five, we are pretty sure that the child will have learned that being bitten hurts, and that her biting is therefore unacceptable. And by the time she is ten years old, we are certain that the intellectually and emotionally normal child will have learned that such behavior is forbidden; and we will hold her morally responsible for such actions.

The ability to respect or violate the rights of others thus seems to rely on an intellectual (and emotional?) ability to recognize the harms one can do to another being, and the types of behavior considered to be inappropriate. Some philosophers, such as Michael Tooley, ${ }^{3}$ have tried to make the possession of a right contingent on a similar level of intellectual competence, but for the most part we recognize no such intellectual prerequisite for the possession of rights. There are many real disagreements in the literature over what is to be said to have rights, and why, and so I shall not attempt to give a list of sufficient conditions for possessing rights. Perhaps all that is common to the various accounts is the idea that the entity must be able to suffer harm (on one or another understanding of 'harm').

The fact that there is so much explicit disagreement over that in virtue of which an entity can be said to have a right, along with the fact that there is such implicit agreement in regard to that in virtue of which an entity can violate or respect a right, ${ }^{4}$ leads me to suggest

\footnotetext{
3 “"A Defense of Abortion and Infanticide," in Joel Feinberg, ed., The Problem of Abortion (Belmont, CA: Wadsworth, 1973), p. 60.

${ }^{4}$ As evidenced by the fact that the examples used by those who write on rights never involve inanimate objects violating rights, for example.
} 
that in discussions of rights we are at least as concerned with rights violators or respecters and their behavior as we are with the holders of rights and their possessions.

When we come to see the importance of the concepts of "respecting" and "violating rights" as compared to the concept of "possessing" or "having a right" we can begin to get a clearer picture of both what is correct and what is incorrect about many of the claims often made for rights. For instance, it is often said that the importance of having a right lies in the power it gives one to make a claim for some good. Thus, David Lyons ${ }^{5}$ says;

When $\mathrm{A}$, in particular, holds a certain right against $\mathrm{B}, \mathrm{A}$ is a claimant against B. A "claimant" is one empowered to press or waive a claim against someone with a corresponding duty or obligation. He can, if he wishes, release the other from his obligation and cancel it, or he can insist upon its performance (ibid., p. 60).

If 'to empower' is taken to mean "to give one the power to . . . ," however, one who has a right is certainly not necessarily empowered to press or waive a claim. A kidnapping victim who is bound and gagged certainly does not have the power to press or waive his claims against his captors. Nor does a comatose patient have this power in regard to her physicians or relatives. Moreover, many say that some rights are inalienable - that is, those who are said to hold such rights are disabled from waiving them, such as the rights to life and to liberty. Many persons also feel that at least some animals have some basic rights, such as the right not to be caused pain for no good reason. But to say that the having of a right empowers one to make a claim rules out all animal rights from the very beginning. To this extent, then, the idea that rights empower is incorrect. ${ }^{6}$ Similar examples would also show that rights do not empower others to make claims on behalf of the rightholder.

Nevertheless, we do expect others to refrain from kidnapping us and to help us when we are patients and cannot demand such help. To the extent that society is such that it makes these expectations reasonable we may consider ourselves to be thereby empowered. That is, we are empowered in a substantial way by rights only in so far

\footnotetext{
5 “"Rights, Claimants, and Beneficiaries," in David Lyons, ed., Rights (Belmont, CA: Wadsworth, 1979).

${ }^{6}$ This point should not be confused with the assertion that having a right, or being said to have a right, has nothing to do with making claims. The having of a right is almost certainly necessary in order to press or waive a claim, but it is certainly not sufficient; nor does the pressing of a right guarantee that others will act in the desired manner.
} 
as we are empowered by that behavior of others which we call "respecting rights."

Joel Feinberg ${ }^{7}$ adds an interesting twist to the idea that rights are the grounds of claims. He holds that to have a right is to have a valid claim, and that to have a valid claim involves the ability of those to whom the claim is made to fulfill that claim. In other words, $A$ can only be said to have a valid claim against $B$ to do $X$ if it is within $B$ 's power to do $X$ : and $A$ can only be said to have a right to $X$ if there is someone who is able to do $X$.

An implication of Feinberg's view is that we say of a person that he has a given right only in those situations which involve another entity which is capable of acting in such a way as to be said to be either respecting or violating that right. Therefore, one must know something about the potential rights violator before one can know about a right.

Furthermore, as Feinberg himself notes, we do sometimes want to say of a given person or group of persons that they have certain rights even when, right now, no one is in a position to grant that to which they are said to have a right. He suggests that we admit the existence of claims in such instances, but due to his definition of 'valid claim' he cannot call these claims valid, and therefore cannot associate them with existing rights (though he does call them the "grounds" for future rights). This type of reasoning forces Feinberg to say such things as that persons in underdeveloped countries may not have the right to even a minimal amount of food-e.g., if there is no one in a position to provide that food. He leaves it open how one is to justify the push that is often needed to make a "claim," such as the claim to food, into a "valid claim"; that is, how we would justify insisting that we work toward changing the situation so as to allow others, in the future, to be able to fulfill the claim.

In a similar vein, it is said that rights are necessary for a secure society. Richard Wasserstrom ${ }^{8}$ tells us that,

To live in a society in which there are rights and in which rights are generally respected is to live in a society in which the social environment has been made appreciably more predictable and secure. It is to be able to count on receiving and enjoying more objects of value. Rights have, therefore, an obvious psychological, as well as moral, dimension and significance (ibid., p. 49).

7 “"The Nature and Value of Rights," in Rights, pp. 46-56.

${ }^{8}$ Richard Wasserstrom, "Rights, Human Rights, and Racial Discrimination," in Rights, pp. 78-91. 
Rights are often invoked in this way, but does Wasserstrom's conclusion as to the benefits of rights really follow from what he has said? If it is assumed that rights are the sort of thing persons have whether or not any one can be said to be respecting those rights, the conclusion clearly does not follow from the fact that we are said to have rights. In fact, rights do not protect persons from arbitrary harms. No right protects me from being struck by lightning-nor does any moral right protect me from being electrocuted by a sadistic scientist. It is the scientist's behaving in that way which we may call "respecting my right not to be electrocuted" that protects me. As others do elsewhere, Wasserstrom slips in the phrase, above, 'and in which rights are generally respected' as if it were of minimal importance. But, of course, it is precisely persons acting in this way that makes a society secure.

Realizing that rights talk is necessarily concerned with the actions of those we might call potential rights violators allows us to see that an important part of what we are discussing is the behavior of potential rights violators. It is misleading and can be injurious to insist that the existence of a right be established before an action is forbidden. To say that I ought not to punch you because it would hurt you is sufficient - there is no further need to invoke that alleged thing that is your right not to be punched or hurt. Clearly, much of what is to be taken into account is the harm caused by our actions and the significance we give to that harm.

This way of looking at rights talk makes it clear that a debate as to whether or not the members of a certain group-be it dolphins or ethnic minorities - have a given right is largely a debate over how those debating ought to behave toward members of that group. When we see rights in this way we understand that, more than the having of rights, it is what we call recognizing and respecting the rights of others which makes us persons, and raises us above "mere animals."

Hamilton College

HEATHER J. GERT 